\title{
A Nested-Polymerase Chain Reaction Protocol for Detection and Population Biology Studies of Peronospora arborescens, the Downy Mildew Pathogen of Opium Poppy, Using Herbarium Specimens and Asymptomatic, Fresh Plant Tissues
}

\author{
Miguel Montes-Borrego, Francisco J. Muñoz Ledesma, Rafael M. Jiménez-Díaz, and Blanca B. Landa
}

First and third authors: Institute of Sustainable Agriculture (IAS), CSIC, P.O. Box 4084, 14080 Córdoba, Spain and College of Agriculture and Forestry (ETSIAM), University of Córdoba (UCO), Edificio C-4 'Celestino Mutis', Campus de Rabanales, Ctra. Madrid-Cádiz, km 396, 14071 Córdoba, Spain; second author: ALCALIBER S. A., Ctra. Carmona-El Viso del Alcor, km 1.8, Carmona (Sevilla), Spain; and and fourth author: IAS-CSIC, P.O. Box 4084, 14080 Córdoba, Spain.

Accepted for publication 25 September 2008.

\begin{abstract}
Montes-Borrego, M., Muñoz Ledesma, F. J., Jiménez-Díaz, R. M., and Landa, B. B. 2009. A nested-polymerase chain reaction protocol for detection and population biology studies of Peronospora arborescens, the downy mildew pathogen of opium poppy, using herbarium specimens and asymptomatic, fresh plant tissues. Phytopathology 99:73-81.

A sensitive nested-polymerase chain reaction (PCR) protocol was developed using either of two primer pairs that improves the in planta detection of Peronospora arborescens DNA. The new protocol represented an increase in sensitivity of 100- to 1,000-fold of detection of the oomycete in opium poppy tissue compared with the detection limit of single PCR using the same primer pairs. The new protocol allowed amplification of 5 to $0.5 \mathrm{fg}$ of Peronospora arborescens DNA mixed with Papaver somniferum DNA. The protocol proved useful for amplifying Peronospora arborescens DNA from 96-year-old herbarium specimens of

made possible the detection of seedborne Peronospora arborescens in commercial opium poppy seed stocks in Spain with a high frequency, which poses a threat for pathogen spread. Direct sequencing of purified amplicons allowed alignment of a Peronospora arborescens internal transcribed spacer (ITS) ribosomal DNA (rDNA) sequence up to 730-bp long when combining the sequences obtained with the two primer sets. Maximum parsimony analysis of amplified Peronospora arborescens ITS rDNA sequences from specimens of Papaver dubium, $P$. hybridum, $P$. rhoeas, and $P$. somniferum from different countries indicated for the first time that a degree of host specificity may exist within populations of Peronospora arborescens. The reported protocol will be useful for epidemiological and biogeographical studies of downy mildew diseases as well as to unravel misclassification of Peronospora arborescens and Peronospora cristata, the reported causal agents of the opium poppy downy mildew disease.
\end{abstract} Papaver spp. and to demonstrate that asymptomatic, systemic infections by Peronospora arborescens can occur in wild Papaver spp. as well as in cultivated opium poppy. Also, the increase in sensitivity of the protocol
Additional keywords: ancient DNA, biogeography, seed detection.

Opium poppy (Papaver somniferum) is the only source of morphine, codeine, and thebaine alkaloids for the pharmaceutical industry. Opium poppy production is curtailed by downy mildew, one of the most destructive diseases of the crop worldwide $(11,23$, 25,37,43). Two Peronospora spp., Peronospora arborescens and Peronospora cristata, are causal agents of the opium poppy downy mildew disease. They overlap in morphological characters, such as sporangia dimensions, and host range $(25,37)$. This makes it difficult to differentiate between the two pathogens and this may have led to their misclassification in the past.

Historically, herbarium specimens have been an important source for confirmation or redescription of misidentified plant pathogens. Herbarium specimens have also played a paramount role for better understanding plant disease epidemics, especially the biogeography, origin, and dispersal of plant pathogens $(26,33,34)$. Use of current molecular techniques for the study of herbarium specimens has provided accurate diagnostic tools as an alternative to conventional methods for the identification of plants and their

Corresponding author: B. B. Landa; E-mail address: blanca.landa @ias.csic.es

* The $\boldsymbol{e}$-Xtra logo stands for "electronic extra" and indicates that Figure 3 appears in color online.

doi:10.1094/PHYTO-99-1-0073

(C) 2009 The American Phytopathological Society pathogens. For example, use of herbarium specimens from four continents allowed the construction of phylogenetic trees of the internal transcribed spacer (ITS) region of the ribosomal DNA (rDNA) within Peronospora accessions that solved the taxonomic status of the spinach downy mildew and lead to reinstatement of P. effusa as the pathogen on spinach (Spinacea oleracea) (7).

Some downy mildew pathogens have the ability to cause asymptomatic, systemic infections on a wide range of herbaceous crops $(13,44)$, and some evidence was provided that this phenomenon also occurs in the Peronospora arborescens-opium poppy pathosystem (25). Systemic infections by Peronospora arborescens may be of significance in the epidemiology of downy mildew if asymptomatic systemic infections in commercial opium poppy fields give rise to viable infected seed, or if infected wild poppy plants eventually give rise to conidia on leaves that serve as inoculum for opium poppy fields.

In Spain, the rapid spread of opium poppy downy mildew to areas where opium poppy had not been cropped before, together with the progressive increase in the incidence and severity of the disease during the past 5 years, suggested seedborne transmission of the pathogen. Recent research (25) confirmed this hypothesis and demonstrated that (i) Peronospora arborescens can be seedborne on commercial opium poppy seed stocks and (ii) seedborne inoculum can give rise to infected plants under field conditions. For opium poppy downy mildew, a few primary infections by the 
pathogen can give rise to several secondary cycles of infection that result in rapid epidemic development of the pathogen within a field (37). Consequently, efforts should be made to avoid introduction of the pathogen to opium poppy growing areas or fields free from Peronospora arborescens. The ability to detect low amounts of pathogen inoculum on commercial seed stocks is an important disease management tactic.

Species-specific polymerase chain reaction (PCR) protocols have been developed that allow detection of Peronospora arborescens with primer pairs OMPac1fw/OMPac1rv and OMPac7fw/ OMPac7rv (Spanish patent application P200603319, international patent application PCT/ES2007/000781) (25), and Peronospora cristata with primer pair pmd3/pmd4 (36), using total DNA extracted from symptomatic plants or the pathogen as it sporulates on tissues of opium poppy plants. However, use of the Peronospora arborescens-detection protocol developed by Landa et al. (25) was not sensitive enough for pathogen detection in herbarium specimens or commercial seed stocks (B. B. Landa, unpublished data). The specific objectives of this study were to (i) improve the sensitivity of the single-PCR protocol developed by Landa et al. (25) by designing a new nested-PCR protocol that allows amplification of Peronospora arborescens DNA from old herbarium specimens, as well as from asymptomatic, infected plants of Papaver spp. and commercial opium poppy seed stocks; (ii) determine the occurrence of asymptomatic systemic infections of Peronospora arborescens in wild Papaver spp. and commercial opium poppy plants; and (iii) study the genetic diversity within Peronospora arborescens populations from different geographical origins and host plants.

\section{MATERIALS AND METHODS}

Plant materials and herbarium specimens. Seven herbarium specimens were provided by 'Real Jardín Botánico', Spanish Council for Scientific Research, Madrid (Table 1). Some of the samples, especially ancient ones, showed no appearance of sporangia or oospores as determined by microscopic observations. Leaf samples from symptomatic and asymptomatic Papaver spp. plants collected from opium poppy growing areas in Spain were also used for the study (Table 1).

To study the occurrence of asymptomatic systemic infections, 75 opium poppy plants grown under controlled conditions in a soil naturally infested by Peronospora arborescens were sampled when plants had formed a capsule in the main stem. This soil was collected from a commercial opium poppy field plot with high incidence of downy mildew and was proven to contain oospores of the pathogen (M. Montes-Borrego, B. B. Landa, J. A. NavasCortès, F. J. Muñoz-Ledesma, and R. M. Jiménez-Díaz, unpublished data). For that purpose, a 4- to 5-cm-long piece of the basal stem was cut from each plant with sterile scissors, washed with sterile distilled water, and peeled off with a sterile scalpel. Sampled tissues were ground into $0.3-$ to $0.5-\mathrm{g}$ pieces, placed in $1.5-\mathrm{ml}$ Eppendorf tubes, and frozen immediately in liquid nitrogen before DNA extraction.

Additionally, to validate the utility of the nested-PCR protocol for detection of the pathogen in opium poppy seed, 18 commercial seed stocks, provided by ALCALIBER S.A. (Carmona, Sevilla, Spain) were analyzed to determine the presence of Peronospora arborescens in seed. Seed stocks derived from commercial fields in the main opium poppy growing areas of Andalucia and Castilla-La Mancha regions of Spain were obtained by ALCALIBER S.A. following the conventional industrial processes. These seed stocks were collected by the company to be sown in commercial fields the following year. Therefore, the fields from which the commercial seed stocks were collected were selected from among those where the downy mildew disease either was not apparent or disease symptoms were rated low (0 to 1 symptomatic plants $/ \mathrm{m}^{2}$ ) (F. J. Muñoz-Ledesma, personal communication). In addition, seven seed stocks originating from opium poppy crops in France, for which there was no additional information, were used in the study to include opium poppy cultivars different from those cropped in Spain. Three samples from each seed stock were processed for DNA extraction as described below.

DNA extraction and quantification. Genomic DNA was extracted using the Spin Fast DNA kit (Qbiogene, Madrid) as described (25). Pieces of fresh leaf tissue $\left(\approx 2 \mathrm{~cm}^{2}, 30\right.$ to $\left.80 \mathrm{mg}\right)$ from symptomatic and asymptomatic Papaver spp. plants (Table 1) were placed in a 1.5 -ml Fast DNA tube containing lysing matrix A, $800 \mu \mathrm{l}$ of cell lysis/DNA solubilizing solution for vegetation, and $200 \mu \mathrm{l}$ of protein precipitation solution (PPS). Seed samples ( $\approx 500$ seeds, 150 to $200 \mathrm{mg}$ ), stem samples ( $\approx 50$ to $100 \mathrm{mg})$, and pieces of dry herbarium specimens $\left(\approx 2 \mathrm{~cm}^{2}, 3\right.$ to $8 \mathrm{mg}$ ) (Table 1) were processed as described above but allowed to soften in the buffer for $1 \mathrm{~h}$ before processing. Cells were mechanically disrupted in a Fast Prep System Bio 101 (Qbiogene) by reciprocal shaking of samples for $30 \mathrm{~s}$ at 5.5 speed. Subsequently, the supernatant was collected by centrifugation $(10 \mathrm{~min}$ at $12,000 \times g$ ) and processed with the Fast DNA kit according to the manufacturer's instructions.

Extracted DNA was quantified using the Quant-iT DNA Assay Kit Broad Range fluorometric assay (Molecular Probes Inc., Leiden, The Netherlands) and a Tecan Safire fluorospectrometer (Tecan Spain, Barcelona, Spain) according to manufacturer's instructions, and diluted to $20 \mathrm{ng} / \mu \mathrm{l}$ with ultrapure sterile water (USW).

Nested specific-PCR protocol. Primer DC6, specific for Pythiales and Peronosporales oomycete species (3), and the uni-

TABLE 1. Host source, geographic origin, collection number and internal transcribed spacer ribosomal DNA GenBank accessions from Peronospora arborescens samples used in the study

\begin{tabular}{|c|c|c|c|c|c|}
\hline Host source & Sample tissue & Geographic origin & Collection no. ${ }^{\mathrm{a}}$ & Year & GenBank \\
\hline Papaver dubium & Leaves, herbarium specimen & Puerto San Glorio, León, Spain ${ }^{b}$ & $27841(*)$ & 1990 & EU570198 \\
\hline P. dubium & Asymptomatic leaves, fresh tissue & Marchena, Sevilla, Spain & B30 & 2006 & EU570202 \\
\hline P. hybridum & Asymptomatic leaves, fresh tissue & Antequera, Málaga, Spain & R74 & 2004 & EU570208 \\
\hline P. rhoeas & Sporulated leaves, fresh tissue & Malpica de Tajo, Toledo, Spain & $\mathrm{R} 1$ & 2004 & EU570203 \\
\hline P. rhoeas & Asymptomatic capsule, fresh tissue & Antequera, Málaga, Spain & R76 & 2004 & EU570205 \\
\hline P. rhoeas & Asymptomatic leaves, fresh tissue & Antequera, Málaga, Spain & R75 & 2004 & EU570204 \\
\hline P. rhoeas & Leaves, herbarium specimen & Algeria, Africa ${ }^{\mathrm{b}}$ & 15749 & 1912 & EU570196 \\
\hline P. rhoeas & Leaves, herbarium specimen & Puerto de Canales, Burgos, Spain ${ }^{\mathrm{b}}$ & $27844(*)$ & 1990 & EU570197 \\
\hline P. rhoeas & Leaves, herbarium specimen & Naroba, Cantabria, Spain ${ }^{\mathrm{b}}$ & $27843(*)$ & 1990 & EU570199 \\
\hline P. rhoeas & Leaves, herbarium specimen & Constanta, Hagieni, Romania ${ }^{b}$ & 9164 & 1977 & EU570201 \\
\hline P. somniferum & Leaves, herbarium specimen & Lepola, Pornainen, Finland ${ }^{b}$ & 28507 & 1916 & EU570200 \\
\hline P. somniferum & Asymptomatic stem, fresh tissue & Growth chamber experiments & D175 & 2007 & EU570206 \\
\hline P. somniferum & Seed from commercial seed stocks, fresh tissue & ALCALIBER S.A. & D120 & 2007 & EU570207 \\
\hline
\end{tabular}

a Asterisk (*) indicates samples collected by Arne Gustavsson and referenced in Gustavsson (18).

b Samples provided by Herbarium Real Jardin Botanico, CSIC, Madrid (29). 
versal ITS4 primer (42), were used for the first round of amplifications in the nested-PCR protocol using $1 \mu \mathrm{l}$ of DNA from tissues of either symptomatic or asymptomatic poppy plants in $25-\mu 1$ reaction volumes as described (25). Purified Peronospora arborescens DNA (1 ng) and USW were used as positive and negative controls, respectively. The amplified product was diluted $1: 1,1: 5,1: 10,1: 50$, and 1:100 with USW to optimize sensitivity and decrease background effects of the first PCR on the second PCR and subsequent direct sequencing quality. This diluted PCR product $(1 \mu \mathrm{l})$ was used for the second round of amplification in the nested-PCR protocol using primer pairs OMPac1fw $\left(5^{\prime}-\mathrm{CC}\right.$ ACACCTAAAAACTTTCC-3')/OMPac1rv (5'-AACACTCCTCCATTATCG-3') (set P3) or OMPac7fw (5'-GAACGCATATTGCACTTCC-3')/OMPac7rv (5'-CGCACAACACAAATTTCC-3') (set P6) and PCR conditions described by Landa et al. (25).

All reactions (both first- and second-round PCR) were repeated at least twice and always included a positive control (Peronospora arborescens DNA obtained from sporangiophores with sporangia scraped from sporulating leaves) and negative controls including (i) four Papaver somniferum DNA samples from sterile disinfested seed (two samples) and from seedlings grown under sterile conditions (two samples) that consistently tested negative in previous experiments and (ii) four reactions with no DNA (water blanks). None of the negative controls yielded the PCR product, indicating that positive assays were genuine and were not due to cross-contaminations with templates. Additionally, to ensure the validity of the nested-PCR results, all amplicons from herbarium specimens and Papaver spp. samples and 25\% of amplicons from plant and seed stock samples were sequenced (see below).

Amplification products were separated by electrophoresis in $1.5 \%$ agarose gels in $1 \times$ Tris-acetate-EDTA buffer for 60 to $120 \mathrm{~min}$ at $80 \mathrm{~V}$, stained with ethidium bromide, and visualized under UV light. The Gene-ruler DNA ladder mix (Fermentas, St Leon-Rot, Germany) was used for electrophoresis.

Sensitivity of the nested-PCR protocol. Sensitivity of the nested-PCR protocol was assessed and compared with the single PCR assay described by Landa et al. (25). Peronospora arborescens DNA was diluted in USW as well as in Papaver somniferum DNA extracted from healthy opium poppy leaves $(25$ or $50 \mathrm{ng} / \mu \mathrm{l})$ to reach DNA concentrations ranging from $50 \mathrm{pg}$ to $0.005 \mathrm{fg}$ (Table 2). Special care was taken to get accurate pathogen and host DNA concentrations by fluorimetric quantification using the Quant-iT DNA Assay Kit as described above in triplicate and in two independent plates. All PCR reactions were repeated twice by independent operators using the conditions above and always included $P$. somniferum DNA or no DNA as negative controls.

DNA sequencing and phylogenetic analysis. Products of the second-round PCR were purified using a Geneclean turbo kit (QBIOgene, Illkirch, France), quantified fluorometrically, and used for direct DNA sequencing with the same primers used in each second-round amplification. DNA sequencing was done on a multicapilar sequencer (ABI PRISM 3100 genetic analyzer; Applied Biosystems) at the University of Córdoba sequencing facilities.

TABLE 2. Sensitivity of Peronospora arborescens-specific primers used in single- and nested-polymerase chain reaction (PCR) protocols and of oomycete universal primers using purified DNA of Peronospora arborescens singly or mixed with host DNA

\begin{tabular}{|c|c|c|c|c|c|c|c|c|c|c|}
\hline \multirow[b]{2}{*}{ Primer pair, DS, DNA $(\mathrm{ng} / \mu \mathrm{l})^{\mathrm{a}}$} & \multicolumn{8}{|c|}{ DNA of Peronospora arborescens $(\mathrm{fg} / \mu \mathrm{l})^{\mathrm{b}}$} & \multicolumn{2}{|c|}{ Control } \\
\hline & 50,000 & 5,000 & 500 & 50 & 5 & 0.5 & 0.05 & 0.005 & Negative & $\mathrm{H}_{2} \mathrm{O}$ \\
\hline \multicolumn{11}{|l|}{ DC6/ITS4 } \\
\hline \multicolumn{11}{|l|}{ I } \\
\hline 25 & $+/+$ & -1 & $-/-$ & $-1-$ & $-1-$ & $-1-$ & $-1-$ & $-1-$ & $-1-$ & $-1-$ \\
\hline \multicolumn{11}{|l|}{ II } \\
\hline 0 & $+/+$ & $\pm /-$ & $-1-$ & $-1-$ & $-1-$ & $-1-$ & $-1-$ & $-1-$ & $\ldots$ & $-1-$ \\
\hline \multicolumn{11}{|l|}{ I } \\
\hline 0 & $+/+$ & $+/+$ & $\pm /-$ & $-1-$ & $-1-$ & $-1-$ & $-1-$ & $-1-$ & $\ldots$ & $-1-$ \\
\hline 25 & $+/+$ & $+/+$ & $+/ \pm$ & $-1-$ & $-1-$ & $-1-$ & $-1-$ & $-1-$ & $-1-$ & $-1-$ \\
\hline \multicolumn{11}{|l|}{ II } \\
\hline 0 & $+/+$ & $+/+$ & $\pm /-$ & $-1-$ & $-1-$ & $-1-$ & $-1-$ & $-1-$ & $\ldots$ & $-1-$ \\
\hline 50 & $+/+$ & $+/+$ & $\pm / \pm$ & $-1-$ & $-1-$ & $-1-$ & $-1-$ & $-1-$ & $-1-$ & $-1-$ \\
\hline \multicolumn{11}{|l|}{ OMPac7fw/OMPac7rv (P6) } \\
\hline 50 & $+/+$ & $+/+$ & $+/+$ & $-1-$ & $-1-$ & $-1-$ & $-1-$ & $-1-$ & $-1-$ & $-1-$ \\
\hline \multicolumn{11}{|c|}{ DC6/ITS4 (1st PCR) + P3 (2nd PCR) } \\
\hline \multicolumn{11}{|l|}{ I } \\
\hline 0 & $+/+$ & $+/+$ & $+/+$ & $+/+$ & $\pm /-$ & $-1-$ & $-1-$ & $-1-$ & $\ldots$ & $-1-$ \\
\hline 25 & $+/+$ & $+/+$ & $+/+$ & $+/+$ & $+/+$ & $-1-$ & $-1-$ & $-1-$ & $-1-$ & $-1-$ \\
\hline \multicolumn{11}{|l|}{ II } \\
\hline 0 & +1 & +1 & +1 & +1 & $+/+$ & $-1-$ & $-1-$ & $-1-$ & $\ldots$ & $-1-$ \\
\hline 50 & +1 & +1 & +1 & +1 & $+/+$ & $-1-$ & $-1-$ & $-1-$ & $-1-$ & $-1-$ \\
\hline \multicolumn{11}{|c|}{ DC6/ITS4 (1st PCR) + P6 (2nd PCR) } \\
\hline \multicolumn{11}{|c|}{ I } \\
\hline 0 & $+/+$ & $+/+$ & $+/+$ & $+/+$ & $+/ \pm$ & $+/ \pm$ & $-1-$ & $-1-$ & $\ldots$ & $-1-$ \\
\hline 25 & $+/+$ & $+/+$ & $+/+$ & $+/+$ & $+/+$ & $+/+$ & $-1-$ & $-1-$ & $-1-$ & $-1-$ \\
\hline \multicolumn{11}{|l|}{ II } \\
\hline 0 & $+/+$ & $+/+$ & $+/+$ & $+/+$ & $\pm /+$ & $\pm /-$ & $-1-$ & $-1-$ & $\ldots$ & $-1-$ \\
\hline
\end{tabular}

a Primers OMPac1fw/OMPa1rv (set P3) and OMPac7fw/OMPac7rv (set P6) are protected under Spanish patent application P200603319.

${ }^{\mathrm{b}}$ Peronospora arborescens DNA $(10 \mathrm{ng} / \mu \mathrm{l})$ was serially diluted to obtain $50 \mathrm{pg}$ to $0.005 \mathrm{fg}$ of pathogen DNA per microliter of PCR reaction in sterile distilled water (0 ng of background DNA) or in Papaver somniferum DNA (dilution series [DS] I and DS II = background DNA at 25 or $50 \mathrm{ng} / \mu \mathrm{l}$, respectively) to investigate any possible influence of host DNA on amplification of pathogen DNA. Results were obtained by two independent operators with the same dilution series; $+=$ positive amplification, $\pm=$ positive weak amplification, and $-=$ no amplification . 
All amplifications and DNA sequencing were performed twice to assess reproducibility of chromatograms. All ITS1-5.8S-ITS2 sequences obtained from Peronospora arborescens collections in the study were deposited in GenBank with the accession numbers recorded in Table 1. Sequences generated in this study were aligned with the Peronospora spp. data set described by Landa et al. (25). A maximum parsimony (MP) analysis was performed (Bionumerics 5.1 software; Applied Maths, Kortrijk, Belgium) using either all Peronospora spp. sequences or only Peronospora arborescens sequences. The phylograms were bootstrapped 1,000 times to assess the degree of support for the phylogenetic branching indicated by the optimal trees.

\section{RESULTS}

Nested-PCR protocol. Best amplification results of the nestedPCR protocol were achieved using a 1:10 dilution of the first PCR product as template for the second round (Fig. 1A). The 1:10 dilution allowed similar levels of sensitivity compared with using 1:1 and 1:5 dilutions, with the benefit that background effects were lower and the chromatogram signal after direct sequencing was clean, thus avoiding an intermediate need for cloning the fragment (see below).

The PCR detection limit for single-PCR assays was similar to that reported previously (1 to $10 \mathrm{pg}$ of Peronospora arborescens DNA for primer pairs OMPac1fw/OMPac1rv [set P3] or OMPac7fw/OMPac7rv [set P6]) (25). Conversely, the detection limit for nested-PCR was 0.5 and $0.05 \mathrm{fg}$ of Peronospora arborescens DNA using either primer set P3 or P6, respectively. This represented an increase in sensitivity of 100- to 1,000-fold for primer sets P3 and P6, respectively, compared with the detection limit of single PCR using the same primer pairs (Table 3; Fig. 2). In general, the detection limit was similar when the pathogen DNA was diluted with USW or plant DNA (25 or $50 \mathrm{ng}$ of host DNA). However, there was a trend to higher sensitivity when host DNA was present in the reaction (Fig. 2). Use of the detection protocol by different operators did not influence reproducibility and consistency of results (Table 2).

Occurrence of asymptomatic infections by Peronospora arborescens. Use of the newly developed nested-PCR protocol allowed detection of Peronospora arborescens DNA from Papaver spp. specimens stored in herbarium from 18 up to 96 years (e.g., Papaver rhoeas sampled from Africa in 1912) (Fig. 1A). Also, positive detection of Peronospora arborescens was achieved with leaves and capsules of asymptomatic Papaver dubium, $P$. hybridum (Fig. 1A), P. rhoeas, and P. somniferum plants (Table 1) grown in commercial opium poppy fields in Andalucia and Castilla-La Mancha regions of Spain (M. Montes Borrego, B. B. Landa, J. A. Navas-Cortès, F. J. Muñoz-Ledesma, and R. M. Jiménez-Diaz, unpublished data). This indicated the potential occurrence of asymptomatic systemic infections. No amplification or weak amplification signals were obtained when those samples were assayed by single PCR using primer sets P3 and P6 (data not shown).

The nested-PCR protocol was more efficacious and sensitive in the detection of asymptomatic systemic infections compared with the single-PCR protocol. Thus, use of the nested-PCR protocol determined that 22 of 75 plants $(22.3 \%)$ grown under controlled conditions in a soil naturally infested with Peronospora arborescens oospores were infected by the pathogen, whereas the singlePCR protocol with the same plants indicated an incidence of only 6 of $75(8 \%)$. In general, primer set P6 was more effective than P3 in detecting infection by the pathogen when used in either singleor nested-PCR assays (data not shown).

Occurrence of Peronospora arborescens in commercial seed stocks. A high percentage of commercial opium poppy seed stocks were infected by the pathogen. This was especially evident for seed harvested from crops in the Castilla-La Mancha region, for which all seed stocks showed positive amplification with primer sets P3 and P6 even when they were used in the singlePCR assay. Primer set P6 was more effective than primer set P3 in the detection of seedborne Peronospora arborescens in commercial seed stocks used in either single- or nested-PCR assays (Table 3 ). Thus, use of primer set P3 in single- and nested-PCR allowed detection of the pathogen in 37.0 and $57.4 \%$ of seed samples, respectively; whereas incidence in similar assays using primer set P6 was $55.6 \%$ (single-PCR) and 79.7\% (nested-PCR) of samples scored positive. Use of the nested-PCR protocol increased the sensitivity of detection and allowed positive diagnosis of infections in commercial opium poppy seed stocks that would have given rise to false negatives if assayed using the single-PCR protocol. This fact was particularly evident for seeds stocks derived from crops in France (Table 3), for which all seed stocks, with the exception of one, were negative in single-PCR assays using primer sets P3 and P6. Conversely, nested-PCR assays using primer set P3 and P6 indicated seedborne inoculum of Peronospora arborescens in four and five of the seven seed stocks, respectively.
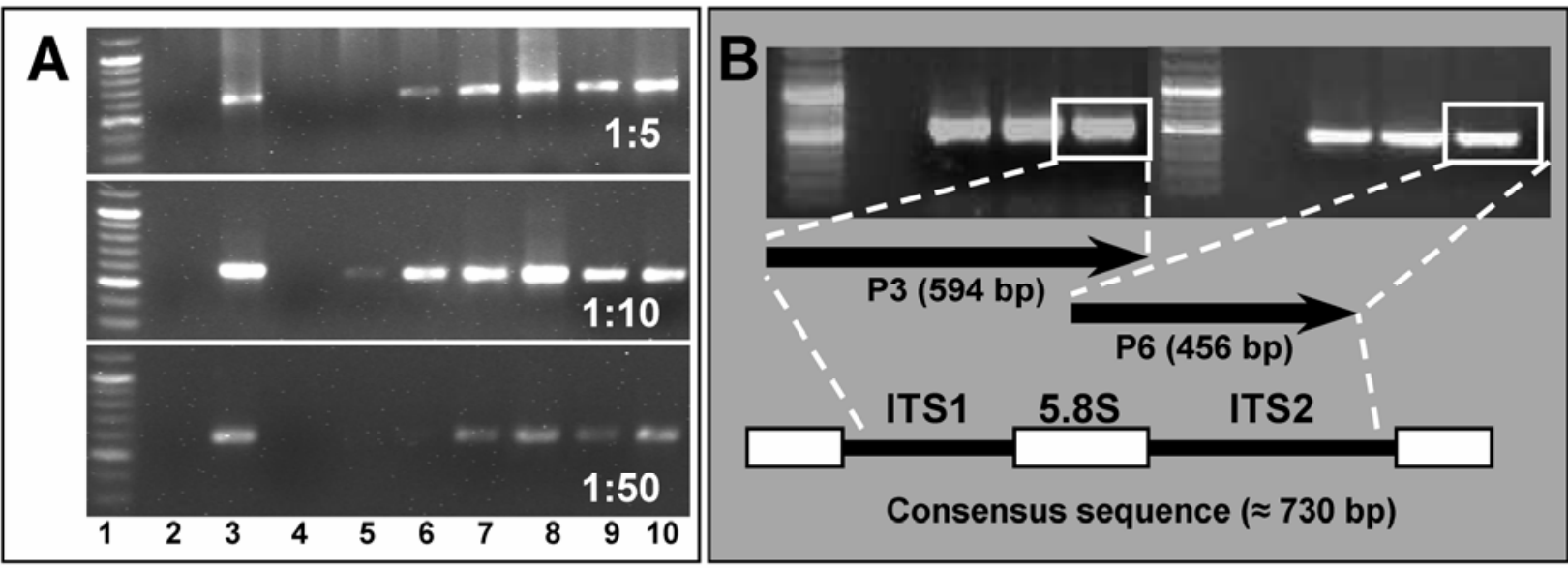

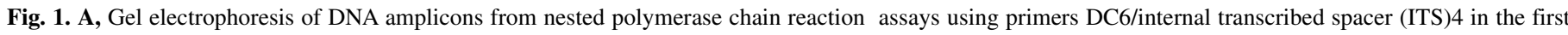

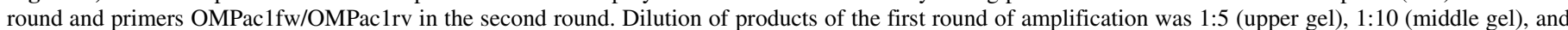

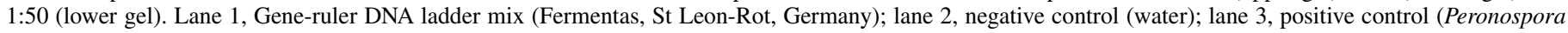

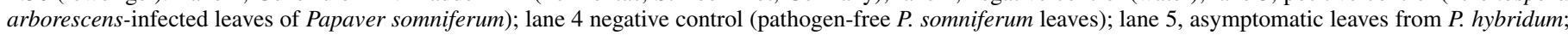

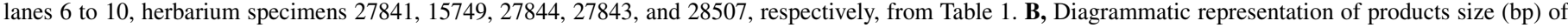

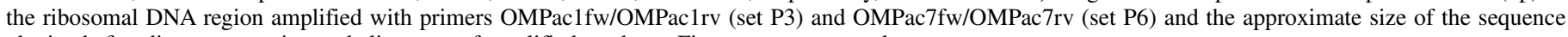
obtained after direct sequencing and alignment of amplified products. Figures are not to scale. 
Sequencing and phylogenetic analysis. Direct sequencing using primers OMPac1fw or OMPac $7 \mathrm{fw}$ of purified amplicons from nested-PCR assays with primer sets P3 and P6 allowed alignment of an ITS1-5.8S-ITS2 rDNA sequence up to $730 \mathrm{bp}$ long when both sequences were combined (Table 1; Fig. 1B). There were no differences in the chromatograms obtained from independent nested-PCR assays when using the same sample or when using either forward or reverse primers (data not shown).

MP analysis using data from all Peronospora spp. in the GenBank database placed all downy mildew specimens in this study in a single clade (100\% support; 99.0 to $99.9 \%$ homology among sequences) which included all Peronospora arborescens sequences from GenBank (data not shown). Interestingly, MP analysis of the Peronospora arborescens data set alone indicated that a degree of host specialization and geographical isolation may exist within Peronospora arborescens populations (Fig. 3). Thus, all sequences of Peronospora arborescens from crops of Papaver somniferum in Spain and France formed a single population together with a specimen from each of $P$. rhoeas and $P$. hybridum from Spain, Peronospora arborescens from a herbarium specimen of Papaver somniferum collected in Finland in 1916 was located in a different clade. On the other hand, Peronospora arborescens isolates from Papaver rhoeas showed higher diversity, with fresh and herbarium specimens from northern Europe and Spain forming a clade different from that including specimens from southern Spain and the one collected in Algeria in 1912. The two isolates from specimens of Papaver dubium formed a third, independent clade (Fig. 3).

\section{DISCUSSION}

In this study, a Peronospora arborescens-specific nested-PCR protocol was developed that (i) strengthens previous findings that only Peronospora arborescens occurs in opium poppy crops and other Papaver spp. in Spain (24,25); (ii) amplifies Peronospora arborescens in ancient, up to 96-year-old, herbarium specimens of different Papaver spp.; and (iii) demonstrates that Peronospora arborescens can generate asymptomatic, systemic infections in both wild Papaver spp. and cultivated opium poppy, and infects seed stocks harvested from crops with low or no symptoms of the disease. Furthermore, phylogenetic analyses of the ITS rDNA indicate that (i) genetic diversity exists within Peronospora arborescens populations occurring worldwide and (ii) a degree of host specificity exists within Peronospora arborescens infecting Papaver spp., with isolates infecting wild poppy being more diverse than those infecting cultivated Papaver somniferum (Fig. 3).

Taxonomic concepts in downy mildew taxa are now considered inadequate and potentially misleading because the taxonomic and evolutionary studies done in the past were based mainly on few

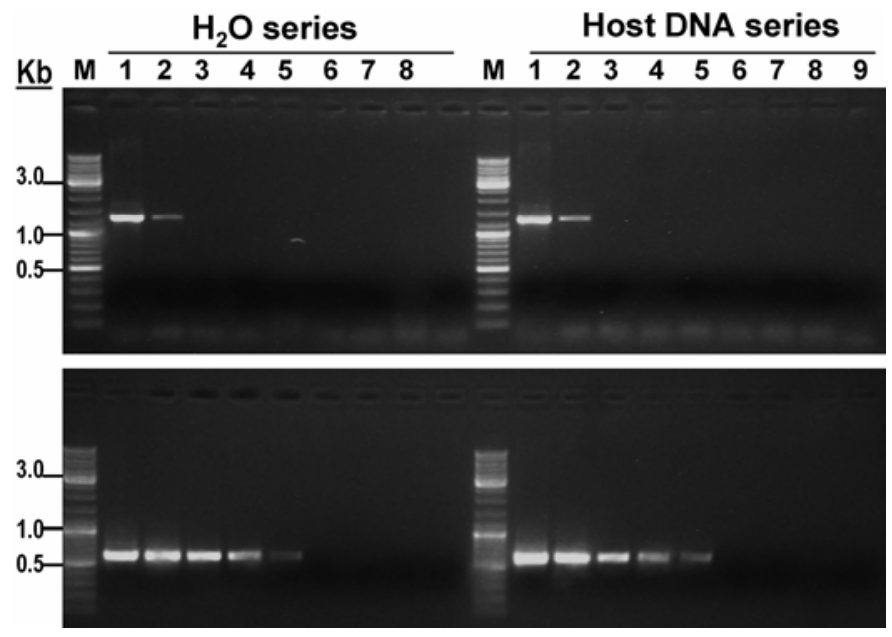

Fig. 2. Sensitivity of Peronospora arborescens-specific primers OMPac $7 \mathrm{fw} /$ OMPac7rv (set P6) in single (upper panel) and nested polymerase chain reaction (lower panel) assays using Peronospora arborescens DNA (50 pg/ $\mu \mathrm{l})$ diluted in water $\left(\mathrm{H}_{2} \mathrm{O}\right.$ series) or in DNA of Papaver somniferum $(50 \mathrm{ng} / \mathrm{\mu l})$ extracted from leaves (Host DNA series). Lane M, Gene-ruler DNA ladder mix (Fermentas, St Leon-Rot, Germany); lanes 1-7, DNA dilution series 1:10

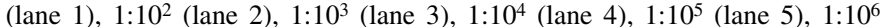
(lane 6), and 1:107 (lane 7); lane 8, no DNA template; lane 9, pathogen-free, disinfested leaves of $P$. somniferum.

TABLE 3. Detection of Peronospora arborescens in naturally infected opium poppy commercial seed stocks using either single- or nested-specific polymerase chain reaction $(\mathrm{PCR})$ assays $^{\mathrm{a}}$

\begin{tabular}{|c|c|c|c|c|c|c|}
\hline \multirow[b]{2}{*}{ Seed code } & \multirow[b]{2}{*}{ Region, cultivar, origin, year } & \multicolumn{3}{|c|}{ Single-PCR } & \multicolumn{2}{|c|}{ Nested-PCR } \\
\hline & & DC6/ITS4 & P3 & P6 & P3 & P6 \\
\hline & Andalucia Region, Spain & & & & & \\
\hline 919 & Madrigal, Castillón invernadero, 2007 & $-1-1-$ & $-1-/ \pm$ & $-/ \pm / \pm$ & $-/+/+$ & $-/++/++$ \\
\hline 922 & Madrigal, Castillón Huerto, 2007 & $\pm /-1-$ & $+/ \pm /-$ & $+/+/+$ & $++/+/+$ & $++/++/++$ \\
\hline 923 & Madrigal, Martín Delgado, 2007 & $-1-1-$ & $-/ \pm /+$ & $+/++/+$ & $+/+/++$ & $++/++/++$ \\
\hline 925 & Madrigal, Las Coronas, 2007 & $-1-1-$ & $\pm /-1+$ & $+/+/++$ & $+/+/++$ & $++/++/++$ \\
\hline 927 & Madrigal, Barbarrota, 2007 & $-1-1-$ & $-1-1-$ & $-1-1-$ & $-1-1-$ & $\pm /+/+$ \\
\hline 931 & Madrigal, Molino gallego, 2007 & $-1-1-$ & $-1-1+$ & $\pm / \pm /+$ & $-/ \pm /++$ & $++/+/++$ \\
\hline \multirow[t]{2}{*}{916} & Madrigal, Viso alto, 2007 & $-1-1-$ & $-1-1-$ & $+/ \pm /-$ & $-1-1-$ & $++/++/+$ \\
\hline & Castilla La Mancha Region, Spain & & & & & \\
\hline 9145 & Madrigal, Casa del Alcalde, 2007 & $\pm /-/ \pm$ & $\pm /+/+$ & $\pm /+/+$ & $++/++/++$ & $++/++/++$ \\
\hline 9147 & Madrigal, Casablanca, 2007 & $\pm /-1-$ & $++/ \pm /+$ & $+/ \pm /++$ & $++/++/++$ & $++/++/++$ \\
\hline 9149 & Madrigal, Casa Nueva, 2007 & $+1+1-$ & $+/+/+$ & $++/++/+$ & $++/++/++$ & $++/++/++$ \\
\hline \multirow[t]{2}{*}{9151} & Madrigal, Los Machorros, 2007 & $-1-1-$ & $+/ \pm / \pm$ & $+/+/ \pm$ & $++/++/++$ & $++/++/++$ \\
\hline & France & & & & & \\
\hline 7519 & V9, 2007 & $-1-1-$ & $-1-1-$ & $-1-1-$ & $-1-1-$ & $-1-1-$ \\
\hline 7521 & Marianne, 2007 & $-1-1-$ & $-1-1-$ & $-1-1-$ & $-1-1-$ & $-1-1-$ \\
\hline 7522 & V40, 2006 & $-1-1-$ & $-1-1-$ & $+/+/-$ & $+/ \pm /-$ & $++/+/-$ \\
\hline 7523 & V40, 2006 & $-1-1-$ & $-1-1-$ & $-1-1-$ & $-1 \pm /-$ & $-/+/+$ \\
\hline 7524 & V40, 2007 & $-1-1-$ & $-1-1-$ & $-1-1-$ & $+/+/-$ & $++/++/-$ \\
\hline 7526 & V9, 2006 & $-1-1-$ & $-1-1-$ & $-1-1-$ & $+1-1-$ & $++/++/-$ \\
\hline 7527 & Marianne, 2007 & $-1-1-$ & $-1-1-$ & $-1-1-$ & $-1-1-$ & $\pm / \pm / \pm$ \\
\hline
\end{tabular}

a Peronospora arborescens-specific primers OMPac1fw/OMPa1rv (set P3) and OMPac7fw/OMPac7rv (set P6) were used in nested- and single-PCR assays (25). Primer DC6, specific for Pythiales and Peronosporales oomycetes (3), and the universal internal transcribed spacer 4 primer (42), were used for the first round of amplifications in the nested-PCR protocol. Then, $1 \mu \mathrm{l}$ of a 1/10 dilution of the first PCR product was used for the second round of amplification in that protocol. Results of DNA amplification from three seed samples; ++= positive amplification (very intense),$+=$ positive amplification, $\pm=$ positive weak amplification, and $-=$ no amplification 
morphological characters and host preference $(5,9,19)$. This has caused much confusion concerning species definition and delimitation, especially when following Gaümann's concept of biological species "one host-one parasitic species" $(12,19$, 41). Recently, phylogenetic analyses of rDNA sequences in the family Peronosporales have helped to resolve taxonomic and phylogenetic relationships among closely related species within Peronospora and allied genera $(5-7,10,17,32,41)$. For instance, Peronospora sparsa from Rosa spp. and P. rubi from Rubus spp. share identical ITS sequences, as do Peronospora viciae from faba bean (Vicia faba) and Peronospora viciae from pea (Pisum sativum), which suggest conspecificity $(4,10)$. Conversely, Hyaloperonospora parasitica from Arabidopsis spp. differs in ITS sequences from the pathogen that infects Brassica oleracea, which suggests reproductive isolation of the two populations (30).

Previous phylogenetic analyses and species-specific PCR assays of the ITS rDNA sequence demonstrated that Peronospora arborescens is the sole causal agent of opium poppy downy mildew in commercial crops in France and Spain $(24,25,27)$. Similar studies demonstrated that Peronospora cristata but not Peronospora arborescens is the downy mildew pathogen in opium poppy crops in Tasmania (Australia) (37). Peronospora cristata has been reported in different countries, including Australia, Bulgaria, England, Ireland, Portugal, Ukraine, and the former USSR (14). Comparatively, the geographic range of Peronospora arborescens appears to be more widespread, because this species has been reported in Afghanistan, Algeria, Andorra, Argentina, Australia,
Austria, Azerbaijan, Belgium, Bulgaria, Canada, Central Asia, China, Egypt, Finland, Germany, Greece, India, Iran, Italy, Japan, Korea, Libya, Mongolia, Pakistan, Poland, Portugal, Romania, South Africa, Sweden, Thailand, Turkey, the United Kingdom, the United States, and Uzbekistan $(14,15)$. In the Iberian Peninsula, Peronospora arborescens has been reported infecting Papaver dubium, $P$. hybridum, and $P$. rhoeas in Spain and wild $P$. somniferum and P. rhoeas in Portugal. Conversely, Peronospora cristata has been reported only in Portugal and infecting Papaver hybridum (16,18). Peronospora arborescens and Peronospora cristata overlap in morphological characters $(15,31,36)$ and host range and, because most previous reports were based on symptoms on the hosts and morphology of the pathogen only, it is possible that some of the descriptions attributed to one of the two species in a country might in fact correspond to the other.

The low degree of morphological diversity in biotrophic oomycetes led to numerous taxa being differentiated according to their host plants rather than by diagnostic characters of the parasites themselves. The ability to trace material that has been stored for a long term (e.g., herbarium specimens) could help to close the gap between traditional, phenetic systematics and recent molecular-based systematics (39). In a recent study using herbarium specimens, Choi et al. (7) showed that Peronospora farinosa from $S$. oleracea is distinct from downy mildew of other chenopodiaceous hosts, which led to reinstatement of Peronospora effusa as the pathogen on spinach. Results of this present work also indicate the usefulness of herbarium specimens for clarifying systematics in Peronospora spp. infecting Papaver spp. Thus, the

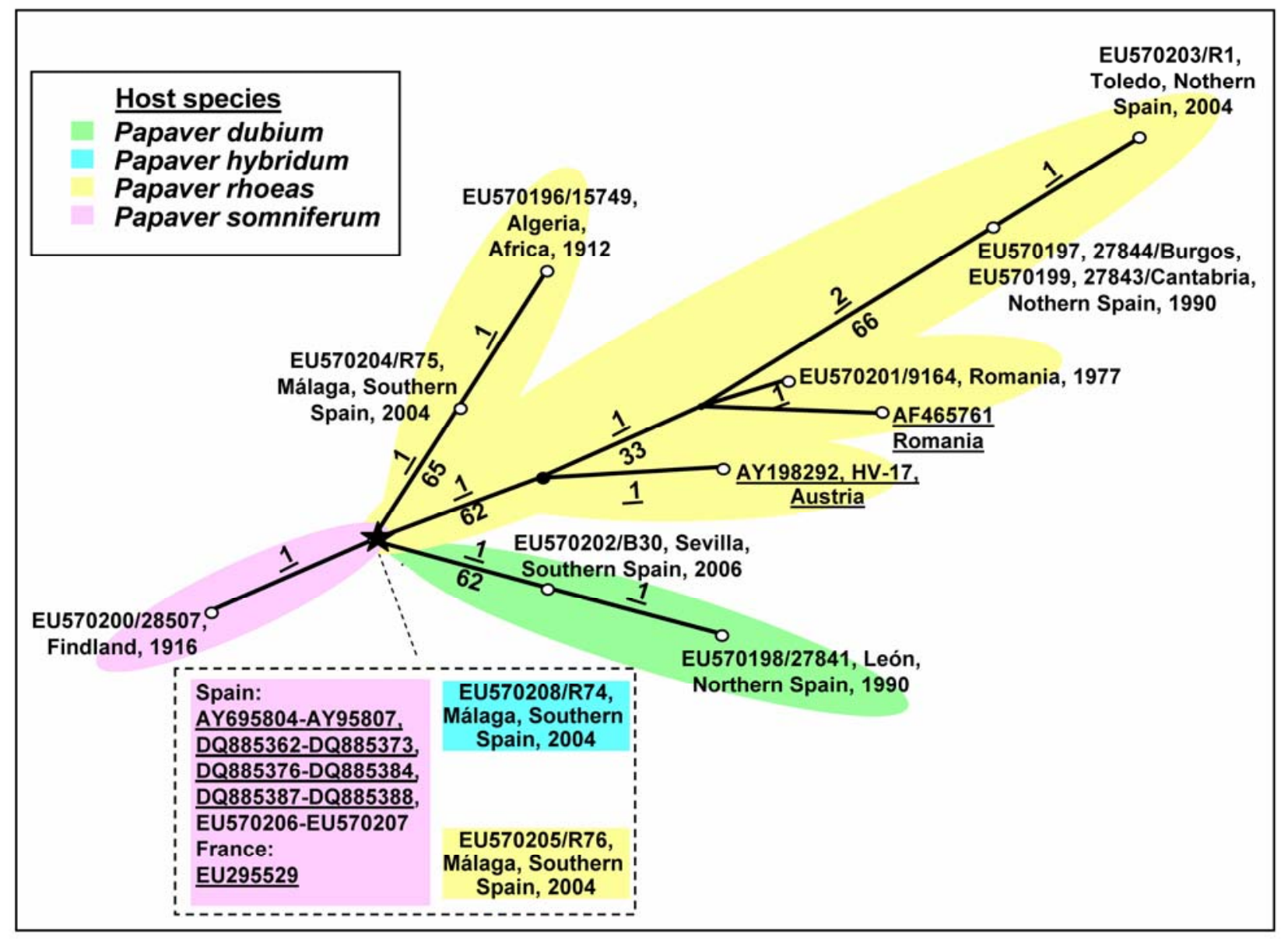

Fig. 3. Maximum parsimony tree from sequences of the internal transcribed spacer (ITS) region (ITS1, 5.8S rDNA, and ITS2) of Peronospora arborescens isolates from samples of herbarium specimens and Papaver spp. (Table 1) and all Peronospora arborescens sequences deposited in the GenBank database (underlined accession numbers). The absolute numbers of nucleotide differences between specimens (underlined numbers) and bootstrap values (\%) are indicated in the branches. The accession number, herbarium code, region, country, and year of collection of specimens are indicated. Host source of Peronospora arborescens isolates is marked in different colors as shown in the legend. $(\star)=$ All Peronospora arborescens isolates included in this node are shown in the frame. 
newly developed nested-PCR protocol confirmed that only Peronospora arborescens is present in herbarium specimens and fresh asymptomatic tissue sampled from different Papaver spp. in Spain, as well as in herbarium specimens of Papaver spp. from Algeria, Finland, and Romania. Ancient herbarium specimens have been scarcely used for phylogenetic studies of downy mildew pathogens and, when used, a clonation step of DNA amplicons was generally required before DNA sequencing (6). The protocol developed in this present research allowed direct sequencing of ancient DNA (up to 96 years old) from an obligate biotroph infecting herbarium specimens, thus avoiding the need of a clonation step. Therefore, this nested-PCR protocol may be useful for elucidating identity of a downy mildew pathogen in herbarium specimens of opium poppy and other Papaver spp. in different areas of the world, as well as to unravel possible misclassification of Peronospora arborescens with Peronospora cristata, the reported causal agents of the opium poppy downy mildew disease.

To the best of our knowledge, MP analysis of amplified ITS rDNA sequences of Peronospora arborescens infecting Papaver dubium, $P$. hybridum, $P$. rhoeas, and $P$. somniferum specimens from different countries indicated for the first time that a degree of host specificity may exist within Peronospora arborescens populations. Interestingly, all sequences of Peronospora arborescens from commercial opium poppy crops in Spain and France formed a single population together with those of isolates from Papaver rhoeas and P. hybridum from Spain that were sampled in commercial opium poppy fields. However, ITS rDNA sequences from Peronospora arborescens infecting wild poppy were genetically more diverse among themselves compared with those of Peronospora arborescens isolates from cultivated Papaver somniferum. It would be productive future work to determine whether Peronospora arborescens isolates infecting opium poppy cultivars in different areas of the world harbor genetic diversity, which would tentatively indicate selection of pathogen genotypes by host genotypes, co-migration with the host plant, or reproductive isolation. Further studies should be done to determine whether Peronospora arborescens populations differing in ITS sequences or host source also differ in host specialization and virulence on Papaver somniferum and Papaver spp., as established for other downy mildews (Chenopodium quinoa/Peronospora farinosa $\mathrm{f}$. sp. chenopodii [28] and $S$. oleracea/Peronospora farinosa f. sp. spinaciae [22]). Ongoing investigations in our laboratory, based in phylogenetic analysis of ITS rDNA sequences, indicate that a downy mildew disease in Papaver hybridum in the field may be caused by a Peronospora spp. different from Peronospora arborescens and Peronospora cristata (M. Montes-Borrego, J. A. Navas-Cortés, R. M. Jiménez-Díaz, and B. B. Landa, unpublished data). This would suggest that pathogen diversity in Papaver spp./downy mildew pathosystems might be greater than initially thought.

Because of the obligate biotrophy of phytopathogenic members of Peronosporales, availability of molecular protocols for their identification as well as in planta and seed detection would be of importance for the implementation of health certification schemes. In previous work (25), we developed a Peronospora arborescensspecific PCR protocol that (i) can be used for pathogen detection in capsules, leaves, roots, seed, and stems of plants; (ii) is sensitive enough to detect 0.1 to $10 \mathrm{pg}$ of Peronospora arborescens DNA; and (iii) has high specificity because no cross-amplification occurs with other closely related pathogens, especially Peronospora cristata in infected opium poppy tissues. The newly developed nested-PCR protocol has greater sensitivity for the in planta detection of Peronospora arborescens DNA increasing by 100- to 1,000-fold the detection limit (depending of the primer set) compared with that of the single-PCR assay using the same primers (25), and maintains the above referred properties of this latter assay. The increased sensitivity of the nested-PCR protocol allowed detection of as little as 5 to $0.5 \mathrm{fg}$ of Peronospora arborescens DNA against a background of 25 to $50 \mathrm{ng}$ of opium poppy DNA. Nested-PCR protocols already developed for the detection of other oomycetes $(21,35,38,40)$ showed detection limits (1 pg to $100 \mathrm{fg}$ of different Phytophthora spp. and of Peronospora tabacina) greater than those achieved in our study. Also, the presence of host DNA in our protocol did not influence the sensitivity of our single-PCR (25) or the nested-PCR protocols in contrast to other studies, where sensitivity was decreased one- to twofold (38).

The new nested-PCR protocol was effective in detecting pathogen DNA when the single-PCR assay either failed to detect it or was less efficacious. This was the case of pathogen detection in ancient herbarium specimens, which demonstrated the occurrence of asymptomatic, systemic infections of Papaver spp. by Peronospora arborescens. Thus, the pathogen was detected in leaves of wild Papaver spp. grown in fields that did not show morphologic symptoms of downy mildew. In previous work, we reported the occurrence of putative systemic infections of opium poppy by Peronospora arborescens in field-grown plants showing dwarfing and rosetting but no other obvious symptom of downy mildew (25). In this present study, we demonstrate that the nested-PCR protocol is more efficient than the single-PCR assay in the detection of asymptomatic, systemic infections of plants grown under controlled conditions, and is more useful for studies on the biology of opium poppy downy mildew. These infections were caused by soilborne inoculum during seed germination or seedling growth (M. Montes-Borrego, B. B. Landa, J. A. Navas, F. J. Muñoz-Ledesma, and R. M. Jiménez-Díaz, unpublished data). Research is ongoing in our laboratory to determine the role of oospores as primary inoculum for development of downy mildew epidemics of opium poppy using the nested-PCR protocol to demonstrate root infection by the pathogen.

Downy mildews are among the most destructive diseases of crops worldwide and can be seedborne. Consequently, efforts should be made to avoid introduction of infected seed into areas where the pathogen does not occur. For instance, specific-PCR assays of 11 commercial sweet basil seed batches of unknown origin (2) indicated the presence of Peronospora spp. in 9 of them. Similarly, oospores of Peronospora effusa were demonstrated in seed of 6 of 11 commercial seed lots of spinach (20) and three of seven maize seed lots were shown to harbor and transmit Peronosclerospora sorghi (1). Recently, we demonstrated that Peronospora arborescens can be seed transmitted and that commercial seed stocks harvested from opium poppy crops with high incidence of the downy mildew disease were frequently infected by the pathogen (25). Use of the nested-PCR protocol developed in this study demonstrated further that the pathogen can be detected in commercial seed stocks harvested from opium poppy crops that have either no evidence or low incidence of the disease. Some of those seed stocks would have given rise to false negatives for presence of the pathogen if the single-PCR assay had been used for detection assays. This fact is particularly important for companies like ALCALIBER S.A., the only enterprise officially authorized for opium poppy cultivation in Spain that aims to select seed stocks for the next year from those fields that have not shown any symptoms of disease. Using the best methods available as practiced by this company, the downy mildew disease has nevertheless spread rapidly to large areas where opium poppy had not been cropped before. This suggests seedborne transmission of Peronospora arborescens because isolation of the sampled crops from other opium poppy crops within a range of several hundreds of kilometres would make it unlikely that distant plantings could serve as a source of airborne, primary inoculum. Studies are in progress to ascertain the biology of systemic infections by Peronospora arborescens and to determine whether or not low inoculum levels of the pathogen on seed may give rise to a high number of infected plants as well as 
whether asymptomatic systemic infection of a plant could give rise to viable, infected seed as demonstrated for other downy mildew pathogens (e.g., Plasmopara halstedii/Helianthus annuus [8] or Peronospora ducometi/Fagopyrum sculentum [44]). In the meantime, the nested-PCR protocol currently is being used by ALCALIBER S.A. to assure use of seed stocks free of infection by the pathogen, discarding infected ones, and to avoid dispersal of the pathogen in seed to opium poppy growing areas free from Peronospora arborescens.

In conclusion, results from this study demonstrate the usefulness of the nested-PCR protocol developed for biogeographic, diagnostic, and epidemiological studies of the opium poppy disease.

\section{ACKNOWLEDGMENTS}

Financial support for this research was provided by grant PET2006_0444 from 'Ministerio de Educación y Ciencia' of Spain and the European Social Fund, and from an 'Intramural Project' to B. B. Landa from the Spanish Council for Research (CSIC). We thank S. Garcés, A. Sánchez, and R. Susín for excellent technical support; P. Castillo and J. A. Navas-Cortés for critically reading the manuscript prior to submission; M. Dueñas, María P. Martín, and M. T. Tellería from Real Jardín Botánico from CSIC, Madrid, Spain for providing the herbarium specimens; and anonymous reviewers and the senior editor for editorial improvement.

\section{LITERATURE CITED}

1. Adenle, V. O., and Cardwell, K. F. 2000. Seed transmission of maize downy mildew (Peronosclerospora sorghi) in Nigeria. Plant Pathol. 49:628-634.

2. Belbahri, L., Calmin, G., Pawlowski, J., and Lefort, F. 2005. Phylogenetic analysis and real time PCR detection of a presumably undescribed Peronospora species on sweet basil and sage. Mycol. Res. 109:12761287.

3. Bonants, P., De Weerdt, M. H., Van Gent Pelzer, M., Lacourt, I., Cooke, D., and Duncan, J. 1997. Detection and identification of Phytophthora fragariae by the polymerase chain reaction. Eur. J. Plant Pathol. 103:345355.

4. Breese, W. A., Schattock, R. C., Williamson, B., and Hackett, C. 1994. In vitro spore germination and infection of cultivars of Rubus and Rosa by downy mildews from both hosts. Ann. Appl. Biol. 125:73-85.

5. Choi, Y.-J., Hong, S.-B., and Shin, H.-D. 2003. Diversity of the Hyaloperonospora parasitica complex from core brassicaceous hosts based on ITS rDNA sequences. Mycol. Res. 107:1314-1322.

6. Choi, Y.-J., Hong, S.-B., and Shin, H.-D. 2005. A re-consideration of Pseudoperonospora cubensis and P. humuli based on molecular and morphological data. Mycol. Res. 109:841-848.

7. Choi Y.-J., Hong, S.-B., and Shin, H.-D. 2007. Re-consideration of Peronospora farinosa infecting Spinacia oleracea as distinct species, Peronospora effusa. Mycol. Res. 111:381-391.

8. Cohen, Y., and Sackston, W. E. 1974. Seed infection and latent infection of sunflowers by Plasmopara halstedii. Can. J. Bot. 52:231-238.

9. Constantinescu, O., and Fatehi, J. 2002. Peronospora-like fungi (Chromista, Peronosporales) parasitic on Brassicaceae and related hosts. Nova Hedwigia 74:291-338.

10. Cooke, D. E. L., Williams, N. A., Williamson, B., and Duncan, J. M. 2002. An ITS-based phylogenetic analysis of the relationships between Peronospora and Phytophthora. Pages 161-165 in: Advances in Downy Mildew Research. P. T. N. Spencer, U. Gisi, and A. Lebeda, eds. Kluwer Academic Publishers, Dordrecht, The Netherlands.

11. Cotterill, P. J., and Pascoe, I. G. 1998. Downy mildew of Papaver somniferum in Tasmania. Australas. Plant Pathol. 27:263-264.

12. Dick, M. W. 2002. Towards an understanding of the evolution of the downy mildews. Pages 1-57 in: Advances in Downy Mildew Research. P. T. N. Spencer, U. Gisi, and A. Lebeda, eds. Kluwer Academic Publishers, Dordrecht, The Netherlands.

13. Döken, M. T. 1986. The nature of systemic invasion of stem and leaves of sunflowers by Plasmopara helianthi Novot. var. helianthi Novot. with mechanism of sporulation and zoospore release. J. Phytopathol. 117:270-275.

14. Farr, D. F., Rossman, A. Y., Palm, M. E., and McCray, E. B. Fungal Databases, Systematic Botany and Mycology Laboratory, U. S. Dep. Agric. Agric. Res. Serv. Online publication retrieved June 2, 2008, from http://nt.ars-grin.gov/fungaldatabases/.
15. Francis, S. M. 1981. Peronospora arborescens. CMI Descriptions of Pathogenic Fungi Bacteria 686:1-2.

16. Garcia-Blazquez, G., Constantinescu, O., Telleria, M. T., and Martin, M. P. 2006. Preliminary checklist of Albuginales and Peronosporales (Chromista) reported from the Iberian Peninsula and Balearic Islands. Mycotaxon 98:185-188.

17. Göker, M., Voglmayr, H., Riethmüller, A.,Weiß, M., and Oberwinkler, F. 2003. Taxonomic aspects of Peronosporaceae inferred from Bayesian molecular phylogenetics. Can. J. Bot. 81:672-683.

18. Gustavsson, A. 1991. The genus Peronospora in the Iberian peninsula, especially in northern Spain and Andorra. An. Jard. Bot. Madrid 49:3-38.

19. Hall, G. S. 1996. Modern approaches to species concepts in downy mildews. Plant Pathol. 45:1009-1026.

20. Inava, T., Takahashi, K., and Morinaka, T. 1983. Seed transmission of spinach downy mildew. Plant Dis. 67:1139-1141.

21. Ippolito, A., Schena, L., and Nigro, F. 2002. Detection of Phytophthora nicotianae and P. citrophthora in citrus roots and soils by nested PCR. Eur. J. Plant Pathol. 108:855-868.

22. Irish, B. M., Correll, J. C., Koike, S. T., and Morelock, T. E. 2007. Three new races of the spinach downy mildew pathogen identified by a modified set of spinach differentials. Plant Dis. 91:1392-1396.

23. Kapoor, L. D. 1995. Opium Poppy: Botany, Chemistry and Pharmacology. Food Products Press, New York

24. Landa, B. B., Montes-Borrego, M., Muñoz-Ledesma, F. J., and JiménezDíaz, R. M. 2005. First report of downy mildew of opium poppy caused by Peronospora arborescens in Spain. Plant Dis. 89:338.

25. Landa, B. B., Montes-Borrego, M., Muñoz-Ledesma, F. J., and JiménezDíaz, R. M. 2007. Phylogenetic analysis of downy mildew pathogens of opium poppy and PCR-based in-planta and seed detection of Peronospora arborescens. Phytopathology 97:1380-1390.

26. Li, W., Brlansky, R. H., and Hartung, J. S. 2006. Amplification of DNA of Xanthomonas axonopodis pv. citri from historic citrus canker herbarium specimens. J. Microbiol. Methods 65:237-246.

27. Montes-Borrego, M., Muñoz-Ledesma, F. J., Jiménez-Díaz, R. M., and Landa, B. B. 2008. Downy mildew of commercial opium poppy crops in France is caused by Peronospora arborescens. Plant Dis. 92:834.

28. Ochoa, J., Frinking, H. D., and Jacobs T. H. 2005. Postulation of virulence groups and resistance factors in the quinoa/downy mildew pathosystem using material from Ecuador. Plant Pathol. 48:425-430.

29. Pando, F. 2000. Bases de datos en línea de las colecciones de criptógamas del Herbario MA. http://www.rjb.csic.es/colecciones_herbario_cripto_ consult.php.

30. Rehmany, A. P., Lynn, J. R., Tör, M., Holub, E. B., and Beynon, J. L. 2000. A comparison of Peronospora parasitica (downy mildew) isolates from Arabidopsis thaliana and Brassica oleracea using amplified fragment length polymorphism and internal transcribed spacer 1 (ITS1) sequence analyses. Fungal Genet. Biol. 30:95-103.

31. Reid, D. A. 1969. New or interesting British plant diseases. Trans. Br. Mycol. Soc. 52:19-38.

32. Riethmuller, A., Voglmayr, H., Göker, M., Weiß, M., and Oberwinkler, F. 2002. Phylogenetic relationships of the downy mildews (Peronosporales) and related groups based on nuclear large subunit ribosomal DNA sequences. Mycologia 94:834-849.

33. Ristaino, J. B. 1998. The importance of archival and herbarium materials in understanding the role of oospores in late blight epidemics of the past. Phytopathology 88:1120-1130.

34. Ristaino, J. B., Groves, C. T., and Parra, G. R. 2001. PCR amplification of the Irish potato famine pathogen from historic specimens. Nature 411:695-697.

35. Schena, L., Duncan, J. M., and Cooke, D. E. L. 2008. Development and application of a PCR-based 'molecular tool box' for the identification of Phytophthora species damaging forests and natural ecosystems. Plant Pathol. 57:64-75.

36. Scott, J. B., Hay, F. S., and Wilson, C. R. 2004. Phylogenetic analysis of the downy mildew pathogen of oilseed poppy in Tasmania, and its detection by PCR. Mycol. Res. 108:98-295.

37. Scott, J. B., Hay, F. S., Wilson, C. R., Cotterill, P. J., and Fist, A. J. 2003. Spatiotemporal analysis of epiphytotics of downy mildew of oilseed poppy in Tasmania, Australia. Phytopathology 93:752-757.

38. Silvar, C., Duncan, J. M., Cooke, D. E. L., Williams, N. A., Díaz, J., and Merino, F. 2005. Development of specific PCR primers for identification and detection of Phytophthora capsici Leon. Eur. J. Plant Pathol. 112:3-52.

39. Spring, O., and Thines, M. 2004. On the necessity of new characters for classification and systematics of biotrophic Peronosporomycetes. Planta 219:910-914.

40. Tsay, J.-G., Chu, C., Chuang, Y.-H., and Chen, R.-S. 2006. Specific detection of Peronospora tabacina by PCR-amplified rDNA Sequences. Plant Pathol. J. 5:78-382.

41. Voglmayr, H. 2003. Phylogenetic relationships of Peronospora and 
related genera based on nuclear ribosomal ITS sequences. Mycol. Res. 107:1132-1142.

42. White, T. J., Bruns, T., Lee, S., and Taylor, J. W. 1990. Amplification and direct sequencing of fungal ribosomal RNA genes for phylogenetics. Pages 315-322 in: PCR Protocols: A Guide to Methods and Applications. M. A. Innis, D. H. Gelfand, J. J. Sninsky, and T. T. White, eds. Academic Press Inc., New York.
43. Yossifovitch, M. 1929. Peronospora arborescens (Berk.) de Bary, parasite tres important de Papaver somniferum en Yougoslavie. Rev. Pathol. Entomol. Agric. 16:235-270.

44. Zimmer, R. C., McKeen, W. E., and Campbell, C. G. 1992. Location of oospores in buckwheat seed and probable roles of oospores and conidia of Peronospora ducometi in the disease cycle on buckwheat. J. Phytopathol. 135:217-223. 